\title{
Disposal and disinfection of organic waste of poultry farms
}

\author{
C Yury I. Sukharev, ${ }^{1{ }^{+}}$Inna Yu. Apalikova, ${ }^{2 *}$ and Vitaly O. Apalikov ${ }^{3 *}$ \\ ${ }^{1}$ Department of Solid State Chemistry and Nanoprocesses. Chelyabinsk State University. \\ Kashirin brothers St., 129. Chelyabinsk, 454001. Ural Federal District. Chelyabinsk Region. \\ Chelyabinsk. Russia.Phone:+7 (900) 78-63-50.E-mail:yuri_sucharev@mail.ru \\ ${ }^{2}$ Department of Mathematics and General Technical Disciplines №6. FGKVOU VPO Federal State \\ Official Military Educational Institution of Higher Professional Education Military Educational-Research Centre \\ of Air Force «Air Force Academy named After Professor N.E. Zhukovsky and Y.A. Gagarin» (Voronezh) of the \\ Ministry of Defence of the Russian Federation (Branch, Chelybinsk); Air Force Academy. MERC AF «AFA» \\ (Branch, Chelybinsk). 454015, Chelyabinsk Town-11 d. 1. Chelyabinsk, Russia. \\ Phone: +7 (908)061-26-81.E-mail: apal-inna@yandex.ru \\ ${ }^{3}$ Department of Road transport. Federal state Autonomous educational institution of higher education "South Ural \\ State University (national research University)". V.I. Lenin Ave., 76. Chelyabinsk, 454080. Uralsky Federal \\ district, Chelyabinsk region, Russia. Federal STATE Autonomous educational institution "South Ural State \\ University (national research UNIVERSITY)» Chelyabinsk, Russia. \\ Phone: +7 (912) 475-17-45. E-mail: apalikov74ru@yandex.ru
}

\begin{abstract}
*Supervising author; ${ }^{+}$Corresponding author
Keywords: chicken manure, gel nanostructures, self-organization, spontaneous nanotocki, wave processes.
\end{abstract}

Abstract

Huge amounts of litter for a number of reasons, accumulated near poultry farms, have become the object of close attention of environmental and Supervisory authorities. Almost all poultry farms of the Russian Federation were in a difficult environmental situation, as the accumulated bird droppings has become a serious source of environmental pollution, because for the disposal of such volumes of bird droppings poultry farms today do not have even the simplest sets of equipment.

The emerging negative trend can lead in the very near future to an ecological disaster of farms with unpredictable negative consequences for the inhabitants of settlements, to the death of flora and fauna not only of poultry, but also of neighboring territories, it is quite possible the emergence of infectious and invasive diseases in humans, animals and birds.

Chelyabinsk region is famous all over Russia for its livestock enterprises, one of the main directions of which is poultry farming. The region is one of the main suppliers of poultry products to the nearby regions of the country.

With large-scale breeding of chickens, a large amount of food waste is formed, the leading of which is chicken manure.

The paper presents nanotechnology reception processing of a chicken dung, based on experimental data, the destruction of the eggs of Giardia, opistorhoz, ascarids in the Indus-Tserovani stochastic resonance nanocluster current splashes, with the passage of the organic colloidal system between carbon and graphite electrodes.

The paper presents a project of a semi-industrial installation for the disinfection of chicken manure, followed by its use as an effective collodic agricultural fertilizer without the use of heat treatment.

\section{References}

[1] Patent for the invention № 2018126981 with priority of 23.07.2018. "Method of study nanotech ferroelectric manifestations of gel oxyhydrates of $\mathrm{d}$ - and f- elements and a device for detecting such nanotoday about pulsing the ferroelectric-phenomena". Sukharev Yu.I., Apalikova I.Yu., Markov B.A. 2018. (russian)

[2] Patent for invention № 2013141099 from 21.12.2018. "The method of disposal and obessa-Rivonia of chicken manure". Sukharev Yu.I., Apalkov V.O., Larionov L.P., Burmistrov V.A., Lebedeva I.Yu.

[3] Yu.I. Sukharev, I.Yu. Apalikova. Nanotube ferroelectrics gel oxyhydrates. Monograph. A series of "Butlerov heritage". Book 1. Kazan: Publishing house OOO "Innovation publishing house "Butlerov heritage". 2019. 440p. (russian)

[4] Yu.I. Sukharev. Nonlinearity of Cooloid Systems: Oxyhydrate Systems. Trans Tech Publications Ltd Laubisrutistr. 24 Switzerland - 2009. 
[5] Yu.I. Sukharev, L.P. Larionov, I.Yu. Apalikova, I.Yu. Lebedeva, A.L. Kuznetsov, E.V. Taramina, N.In. Kuzmina. "Antimicrobial activity of some d- and f- element oxyhydrates against carbon inclusions." "IV international scientific and practical conference" (article). High technologies, fundamental and applied research in physiology and medicine": Collection of articles. St. Petersburg: Publishing house of the Polytechnic University. 2012. November 15-16. Vol.1. P.131-147. (russian)

[6] Yu.I. Sukharev. Wave oscillations in coolloid oxyhydrates. Trans Tech Publications Ltd Laubisrutistr. 24 Switzerland-2015 г.

[7] Yu.I. Sukharev, I.Yu. Apalikova, V.O. Apalkov, I.A. Zasoba. Nonlinear system in nature, as oxyhydrates of zirconium. Bulletin of Tomsk State University, series "Chemistry". 2015. Iss.2. P.30-44. (russian)

[8] Yu.I. Sukharev, I.Yu. Apalikova, V.O. Apalikov. Stochastic transport in ratchet potential (article). Bulletin of Tomsk State University, series "Chemistry". 2015. Iss.400. P.322-329. (russian)

[9] Yu.I. Sukharev, I.Yu. Apalikova: monograph. Cluster Electric Spectroscopy of Colloid Chemical Oxyhydrate Systems. Trans Tech Publications Ltd. Churerstrasse 20. Switzerland -2015г. 585c. ISBN-13:978-3-03835991-3.

[10] Yu.I. Sukharev, I.Yu. Apalikova, and B.A. Markov. Movement as a bifurcation way of the transition of oxyhydrate systems to chaos Butlerov Communications. 2017. Vol.49. No.2. P.13-24. DOI: 10.37952/ROIjbc-01/17-49-2-13

[11] Yu.I. Sukharev, I.Yu. Apalikova, and B.A. Markov. Structural features of colloids of $d$-elements of oxyhydrate. Butlerov Communications. 2017. Vol.49. No.2. P.48-58. DOI: 10.37952/ROI-jbc-01/17-49-2-48

[12] Yu.I. Sukharev, I.Yu. Apalikova, V.O. Apalikov, I.A. Zasoba. Noise pulsations of formation of oxyhydrate gel nanoclusters. Bulletin of Tomsk State University, series "Chemistry". 2016. Iss.2. P.6169. (russian)

[13] V.S. Anishchenko. Introduction to nonlinear dynamics: Studies. Handbook. Moscow-Izhevsk: Institute of computer research. 2002. 144c. (russian)

[14] Yu.I. Sukharev, I.Yu. Apalikova, V.O. Apalkov, I.A. Zasoba. Periodic nature of the current selforganization in oxyhydrate environment. Bulletin of the Tomsk State University, series "Chemistry". 2016. Iss.1(3). P.45-59. (russian)

[15] Yu.I. Sukharev, V.D. Thai, I.Yu. Apalikova, V.O. Apalikov. Colloidal chemical nanoprocesses based on oxyhydrate systems of rare earth elements (article). XVIII international conference on science and technology Russia-Korea-CIS: Proceedings of the conference. Moscow, 2018. Moscow: Moscow state University Publ. 2018. P.131-137. (russian)

[16] Yu.I. Sukharev, B.A. Markov. Nonlinearity of gel oxyhydrate systems. Ekaterinburg: URO RAS. 2005. 468p. (russian)

[17] Utility model "Device for the disposal and decontamination of chicken dung" No. 201916317 from 27.05.2019. Sukharev Yu. I., Apalikov V. O., Apalikova I. Yu. 2019. Russia.

[18] Patent for invention № 2012138878 from 13.09.2012. "Method of destruction of pathogenic and opportunistic microorganisms". Yu.I. Sukharev, I.Yu. Apalikova, I.Yu. Lebedeva. 2012. (russian)

[19] V.M. Osakovsky. Water supply and sanitation in SELSKOE economy: textbook. Moscow: Kolos. 2002. 328p. (russian) 